\title{
Effectivity of blunt end with side hole irrigation needle to eliminate root canal bacteria
}

\author{
Laksmiari Setyowati, Sudarjani Gunawan and Achmad Sudirman \\ Department of Conservative Dentistry \\ Faculty of Dentistry Airlangga University \\ Surabaya - Indonesia
}

\begin{abstract}
The blunt end with side hole irrigation needles have some advantages. They can be placed close to irrigation area, produce turbulent motion of irrigation material, and not push debris to apical. There is no data about the effectiveness of blunt end with side hole irrigation needle to eliminate root canal bacteria in vivo, therefore the research about effectivity of this needle compare to conventional irrigation needle was permormed. In this study 12 samples were used and divided into two groups. The conventional irrigation needle in the first group was used as control and the blunt end with side hole needle was used in the second group. The bacteriological sampling and colony counting was conducted. The paired t-test analysis before and after irrigation showed significant difference on the first and second group. The result indicated that blunt end with side hole needle more effective in eliminating root canal bacteria than conventional needle. Supporting to this study a software of fluent had been done in vitro. The result showed blunt end with side hole needle produced turbulent motion of irrigating liquid and the conventional needle produced laminar motion.
\end{abstract}

Key words: the conventional irrigation needle, the blunt end with side hole needle, root canal bacteria

Correspondence: Laksmiari Setyowati, c/o: Bagian Konservasi Gigi, Fakultas Kedokteran Gigi Universitas Airlangga. Jln. Mayjend. Prof. Dr. Moestopo No. 47 Surabaya 60132, Indonesia.

\section{INTRODUCTION}

The steps of root canal treatment are cleaning the debridement entire pulp tissue and inflamed fluid, root canal preparation, sterilization, and obturation the root canal. The successful of root canal treatment is depends on several factors, that is preparation, sterilization, and obturation of root canal. ${ }^{1,2,3}$

The purposes of root canal preparation are shaping, enlarging, smoothing the root canal wall, and cleaning necrotic tissue and bacteria. On vital teeth, preparation does not only for debridement pulp tissue and shaping root canal wall, but in order to make filling easier. It will be different if we do a preparation of necrotic teeth. Necrotic tissue from root canal must clean until dentin debris which is grinded look white on preparation device. The root canal treatment will failure if we do not clean the debris perfectly. ${ }^{4}$ Debris and bacteria in the one third apical root canal are the important factors in successful of the root canal treatment. Preparation and irrigation of root canal treatment are methods for cleaning root canal. Irrigation procedure will remove organic and anorganic debris. ${ }^{5}$

Hydrogen peroxide $\left(\mathrm{H}_{2} \mathrm{O}_{2}\right)$ in dentistry is used as irrigation solution since it is promoted by Richardson in 1860. The concentration of $\mathrm{H}_{2} \mathrm{O}_{2}$ which is used for irrigation is $3 \%$. The mechanism is by forming white foam from organic material oxidation. If contacts with blood, pus, serum, saliva, and other organic materials, the foam will bring out the root canal debris. The mechanical cleansing effect of $\mathrm{H}_{2} \mathrm{O}_{2}$ plays important function. $\mathrm{H}_{2} \mathrm{O}_{2}$ is a light antiseptic material and not irritate. After irigation with $\mathrm{H}_{2} \mathrm{O}_{2}$, it must be followed by irrigation using sterile aquadest. This step will neutralize $\mathrm{O}$ nasen. ${ }^{1}$

Penetration of irrigation material depend on several variables like root canal configuration, volume of irrigation solution, the type of irrigation solution, and the most important is type of irrigation device. The irrigation device which is used in Airlangga University Dental Hospital is irrigation needle that have sharp tip with hole on the tip. This needle design will produce laminar flow. ${ }^{6}$ This needle has disadvantage. This needle can push debris out to apical. ${ }^{7}$ Another type of irrigation needle is blunt end with side hole irrigation needle. This type has some advantages. The end of this needle is blunt with many kinds of size that are suitable with file diameter, so the needle will close to apical foramen. The shape of blunt end with side hole irrigation needle is hopefully able to clean debris at apical area and not push debris out to apical. It also create turbulent motion irrigation fluid, so it is wished to clean debris effectively and eliminate bacteria in root canal.6,7

$\mathrm{Kahn}^{7}$ performed an experiment that compared the effectivity of irrigation devices such as conventional needle, monoject endodontic, cavi endo ultrasonic micromega 1500 subsonic, and blunt end with side hole needle. The result showed that the blunt end with side hole irrigation needle is effective on maxillar and mandibular position.

There is no research about the effectivity of blunt end with side hole irrigation needle to eliminate bacteria in vivo, so the aim of this research is to examine the effectivity of blunt end with side hole irrigation needle to eliminate root 
canal bacteria in vivo. The advantage of this research is to get the information about effectivity of irrigation needle to eliminate root canal bacteria for support the successful of root canal treatment.

\section{MATERIALS AND METHODS}

The research was clinic experimental with pre-post controlled design and laboratories experimental. The mandibular anterior teeth from patients, age 18-45 years old who visited Airlangga University Dental Hospital, were choose as the samples. The teeth were diagnosed as pulp necrosis due to dental caries with no periapical lesion, straight root canal, no obturation, diameter of root canal can be put the file no. 30 in, male or female, and teeth with close apices.

The samples were divided into 2 groups. Group I (control group) contained six irrigated samples with conventional irrigation needle (Figure 1). Group II contained of six irrigated samples with blunt end with side hole irrigation needle (Figure 2).

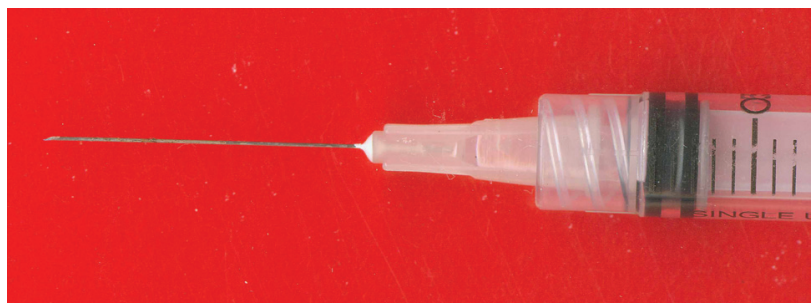

Figure 1. Conventional irrigation needle.



Figure 2. Blunt end with side hole irrigation needle.

Aseptic procedures were done for tools, materials and teeth before the treatment. The teeth were isolated using rubber dam and the cavity entrance was made using a high speed bur. The necrotic pulp tissue was removed with extirpation needle then root canal preparation was done with no. 15 file. Sterile paper point was put in root canal to take the bacteria, ${ }^{9,10}$ then put into media (BHIB) and sent to microbiology laboratory for colony calculation. Root canal preparation was continued with conventional technique until file no. 60 and irrigated using blunt end with side hole irrigation needle on six samples. Another six samples were irrigated using conventional irrigation needle. Irrigation was done with light pressure, so that the irrigation procedure of $2.5 \mathrm{ml}$ irrigation material could be completed in 32 seconds. The location of needle was $4 \mathrm{~mm}$ shorter than working length. Roor canal was dried with five pieces sterile paper point. Root canal bacteria was collected using sterile paper point and put into media (BHIB) and sent to microbiology laboratory of Faculty of Dentistry, Airlangga University for colony calculation. Supporting to this study a software fluent had been done in vitro in Laboratory of Machine Technique, ITS Surabaya.

\section{RESULTS}

The research of the effectivity of blunt end with side hole irrigation needle to eliminate the number of bacteria had been done. Normal distribution test with KolmogorovSmirnov test before and after irrigation, was done for group I and II. It was indicated that the result of all groups was normally distributed with $\mathrm{p}>0.05$. Paired T test was done to compared the difference of bacteria number between control group and treatment group. There was a significant difference $(\mathrm{p}<0.05)$ of bacteria number in necrotic mandibular anterior teeth before and after irrigation between group I and II (Table 1). Using Independent T test, there was a significant difference $(p<0.05)$ between both groups on of bacteria number in root canal of necrotic mandibular anterior teeth (Table 2).

Table 1. The mean, standard deviation and Paired $\mathrm{T}$ test of bacteria number in mandibular anterior teeth after treatment

\begin{tabular}{|c|c|c|c|c|}
\hline \multirow{2}{*}{ Grup } & \multirow{2}{*}{ IN } & \multicolumn{2}{|c|}{$\bar{x} \pm 5 \square$} & \multirow{2}{*}{$F$} \\
\hline & & Etfor & Afrer & \\
\hline $\bar{I}$ & 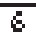 & $10200 \times 12.759$ & $81.57=13.438$ & 0.002 \\
\hline II & $\varepsilon$ & $10200 \times 12.329$ & $31.50 \times 9.160$ & 0.001 \\
\hline
\end{tabular}

Table 2. Statistical result with Independent $T$ test in different number of bacteria in necrotic mandibular anterior teeth root canal between group I and II

\begin{tabular}{|c|c|c|c|}
\hline Group & I & II & $P$ \\
\hline Difference $\overline{\mathrm{X}} \pm \mathrm{SD}$ & $40.17 \pm 16.690$ & $70.50 \pm 15.694$ & 0.009 \\
\hline
\end{tabular}

Conventional irrigation needle produced fluid velocity direction into radial of anterior root canal (Figure 3 ). The conventional irrigation needle which is entered to root canal with depth of $3 / 4$ root canal length, produced spraying pattern in axial direction with teeth axis. The velocity is $1.14-1.37 \mathrm{~m} / \mathrm{s}$ (yellowish green color) (Figure 3-a). Then, the velocity decreased to $0.456-0.685 \mathrm{~m} / \mathrm{s}$ (light blue color) until irrigation material contact with apical foramen and filled at the limit of irrigation needle end, so velocity 

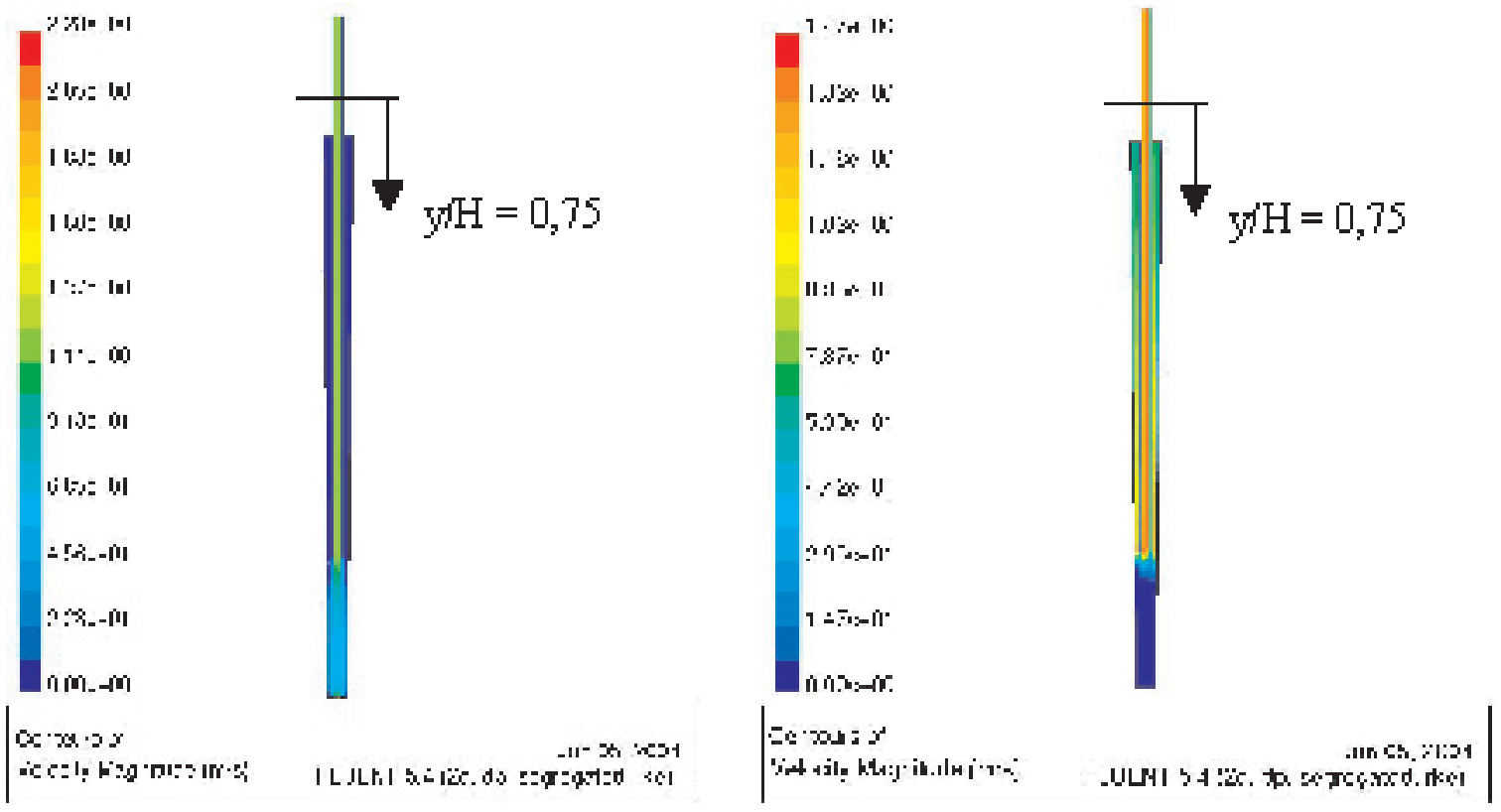

Figure 3. Spray pattern in axial direction (same direction with y axis) for $\mathrm{y} / \mathrm{H}=0,75$.

Numeric Flow pattern of spraying by blunt end with side hole irrigation needle.
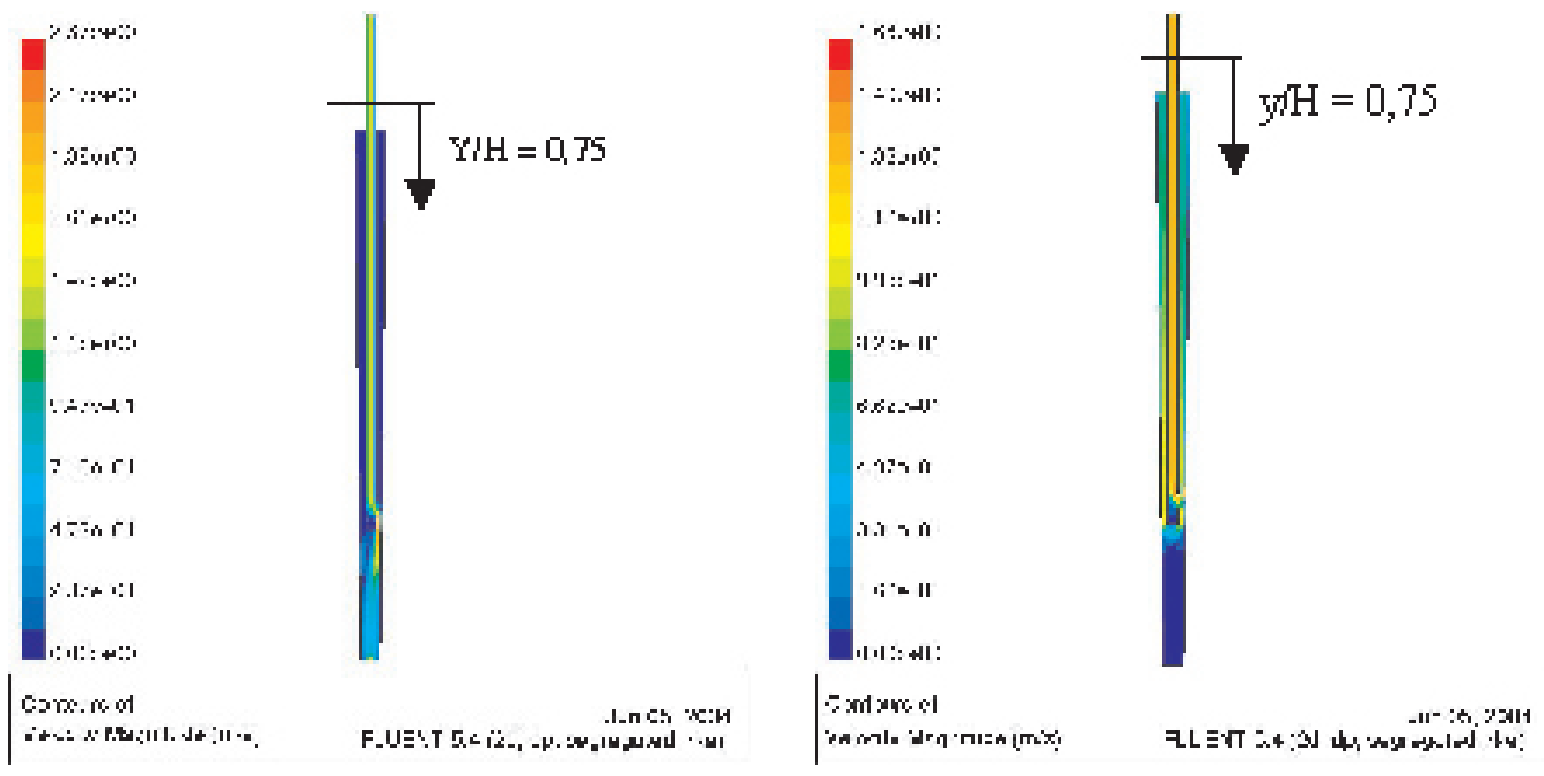

Figure 4. Spraying pattern shapes $90^{\circ}$ angle to y axis for $\mathrm{y} / \mathrm{H}=0.75$.

becomes 0 (dark blue color) (Figure 3-b). After that, the irrigation material flew out with bringing debris with bacteria composition, with velocity of $0.590-0.885 \mathrm{~m} / \mathrm{s}$ (green to yellowish green color).

Blunt end with side hole irrigation needle produced the fluid velocity direction into radial anterior root canal and tangential velocity that contact the inner wall of anterior root canal (Figure 4). The blunt end with side hole irrigation needle which was entered to root canal with depth of $3 / 4$ root canal length, produced spraying pattern shape $90^{\circ}$ angle to teeth axis with velocity of $1.18-1.42 \mathrm{~m} / \mathrm{s}$ (yellowish green color) (Figure 4-a). Then, velocity decreased to
$0.237-0.473 \mathrm{~m} / \mathrm{s}$ (light blue color) until irrigation material contacted with apical foramen and filled at the limit of irrigation needle end, so velocity becomes 0 (dark blue color) (Figure 4-b). After that, the irrigation material flew out with bringing debris with bacteria composition, with velocity of $0.497-0.662 \mathrm{~m} / \mathrm{s}$ (greenish blue color).

\section{DISCUSSION}

In this research, the combination of $3 \% \mathrm{H}_{2} \mathrm{O}_{2}$ and sterile aquadest was used to neutralize $\mathrm{O}_{\mathrm{n} .} 3 \% \mathrm{H}_{2} \mathrm{O}_{2}$ is light 
antiseptic, ${ }^{1}$ We used this irrigation material in order to removed confounding variable. The difference of bacteria number in this research was caused by the difference of irrigation needle, not by the effect of irrigation material. According to Walton and Torabinejad, ${ }^{5}$ irrigation material for root canal must has sterilization or disinfectant characteristic.

This research was supported with in vitro research of software fluent process to examined the irrigation material flow that was sprayed by two kinds of irrigating needles. The result of software fluent process proved that the spray flow of blunt end with side hole irrigation needle was turbulent. This spray flow consists of tangential and radial flow. The spray flow which was resulted by the conventional irrigation needle was laminar. If we examined the numeric flow pattern of spraying irrigation needle, velocity from blunt end with side hole irrigation needle was less than conventional irrigation needle. It is mean, the blunt end with side hole irrigation needle clean the root canal wall more clearer than conventional irrigation needle.

In vivo research indicated that blunt end with side hole irrigation needle decreased bacteria number significantly compared to conventional irrigation needle. Blunt end with side hole irrigation needle produced flow direction velocity of irrigation material into radial direction and also tangential velocity that contact root canal wall. The fusion of this two kinds of velocity clean more debris and bacteria after root canal preparation.

Conventional irrigation needle has a bevel on end side and a hole located on the bevel. This kind of needle will produce flow velocity direction same with teeth axis (axial direction). Whith this flow pattern, part of fluid that contacts with root canal wall and irrigation needle will produce zero velocity, so it can not clean debris and bacteria.

This research indicated that the elimination of the number of bacteria in root canal mandibular teeth was not optimal, therefore it should be irrigated using combination of blunt end with side hole irrigation needle and conventional irrigation needle. By using blunt end with side hole irrigation needle, debris will be accumulate in apical area after irrigation. Irrigation with conventional irrigation needle is for excretion of debris from root canal. This procedure is not valid for maxillary anterior teeth because earth gravitation will cause the debris and bacteria self-excreted after irrigation.

In conclusion, blunt end with side hole irrigation needle is more effective to eliminate root canal bacteria than conventional irrigation needle. The blunt end with side hole irrigation needle is effective as irrigating device for mandibular teeth. For optimal result, we should use the combination between blunt end with side hole irrigation needle and conventional irrigation needle.

\section{REFERENCES}

1. Grossman LI, Oliet S, Del Rio CE. Endodontic practice. $11^{\text {st }}$ ed. Philadelphia: Lea and Febiger; 1988. p. 179, 187-203.

2. Ingle JI, Taintor JF. Endodontics. $3^{\text {rd }}$ ed. Philadelphia: Lea and Febiger; 2001. p. 166-86.

3. Cohen C, Burn RC. Pathways of the pulp. $8^{\text {th }}$ ed. St Louis: Mosby; 2002. p. 231-91.

4. Weine FS. Endodontic therapy. $3^{\text {rd }}$ ed. St Louis, Toronto: Mosby Co; 2003. p. 317- 24.

5. Walton RE, Torabinejad M. Prinsip dan praktik ilmu endodonsi. Edisi ke-2. Jakarta: Penerbit Buku Kedokteran EGC; 1998. p. 277-78.

6. Soedojo P. Fisika dasar. Cetakan ke 2. Andi. Yogyakarta: Penerbit Bhratara; 2000. p. 45-52.

7. Kahn FH, Rosenberg PA, Gliksberg J. An in vitro evaluation of the irritating characteristics of ultrasonic and subsonic hand pieces and irrigating needles and probe. J Endod 1995; 21:277-80.

8. Widodo WA. Pemodelan numerik soft ware fluent. ITS Mesin Surabaya: 2004.

9. Pumarola-Sune J, Sola-Vicens L, Sentis-Vilalta J, Canalda-Sahli C, Brau-Aguade E. Absorbency properties of different brands of standardized endodontic paper point. J Endod 1998; 24:796-98.

10. Edwards RO, Bandyopadhyay S. Physical and mechanical properties 